Teologia i Moralność, Volumen 15(2020), numer 1(27)

doi: 10.14746/tim.2020.27.1.08

ORCID: 0000-0001-6491-1952

\author{
BOGDAN STELMACH
}

Warszawski Uniwersytet Medyczny

\title{
Psychiczno-moralne i społeczne skutki pornografii
}

We współczesnym świecie nowoczesne techniki informatyczne spowodowały konsekwencje, które dostrzegali tylko nieliczni. Nadmiar informacji, do których mamy swobodny dostęp, nie uczynił nas lepiej w nich zorientowanymi, jak się wcześniej wydawało. Raczej zamykamy się w bańkach informacyjnych z emocjonalnie napędzanym wyborem, co jest słuszne, a co nie. Stanowi to pole wszelakich manipulacji, czego polityka jest najlepszym dowodem. Ta warstwa jest jednak postrzegana powszechnie, lecz nie zmienia to faktu, że podatność na nią nadal ma miejsce. Istnieje też obszar słabo postrzeganych manipulacji całymi społecznościami, mający charakter inżynierii społecznej, niedostrzeganych lub ignorowanych, a zarazem pozostających poza obszarem rozumienia, w czym uczestniczymy. Jeżeli czytamy cele brzegowe u nieżyjącej już amerykańskiej feministki w nurcie gender - Shulamith Firestone, to twierdzenie o konieczności ,zniszczenia rodziny i zastąpienia jej polimorficznymi grupami ludzi swobodnie uprawiającymi seks ze zlikwidowaniem szkodliwego tabu homoseksualizmu i kazirodztwa" (por. Środa 2009, s. 132-134) może budzić jedynie uśmiech na twarzy. Wszak żyjemy w społeczeństwie o chrześcijańskich korzeniach i takie rozwiązania społeczne są nieakceptowalne. Jednak analiza świata pornografii doprowadza do odkrycia, że zamierzenia te są realizowane $\mathrm{w}$ obszarze seksualności człowieka, a pornografia stanowi jedno z narzędzi prowadzących do osiągnięcia właśnie tych, wydawało by się, nierealistycznych celów, na sposób nieodwracalny. Początkowo zachęta, a dalej utrwalenie potrzeby wyuzdania seksualnego to proces $\mathrm{w}$ zasadzie nieodwracalny. Jeżeli w dodatku uczynimy to dzieciom, to jest to proces nieodwracalny.

Są osoby, które słusznie nazywają pornografię epidemią XXI wieku. Pornografia definiowana jest jako wizerunek osób lub rzeczy o charakterze jednoznacznie seksualnym. Jest tworzona intencjonalnie, celem wywołania 
podniecenia seksualnego u odbiorcy. W tym ujęciu jest obecna w przestrzeni publicznej, odkąd człowiek nauczył się posługiwać symbolem. W zasadzie obrazowanie aktu seksualnego towarzyszy człowiekowi od zarania dziejów. Problem mamy jednak z pornografią współcześnie dystrybuowaną przez Internet za pomocą szybkiego transferu, bo taka jest przedmiotem niniejszych rozważań. To zupełnie inna pornografia i to ona stanowi problem. Ludzie wychowani w połowie XX stulecia na nośnikach znanych ze swojej młodości nie są $\mathrm{w}$ stanie dostrzec zagrożenia. Współczesna pornografia zlewa im się z tą dawną. Podobieństwo powoduje wrażenie, że mamy do czynienia z tym samym zjawiskiem. Tutaj trzeba wyraźnie powiedzieć, szybki transfer internetowy, do jakiego mamy powszechnie dostęp, zmienił wszystko, co jest związane z pornografią, szczególnie jeśli chodzi o jej szkodliwość dla konsumenta.

Ta cecha pornografii stanowi pułapkę dla jej odbiorców. Nastąpiła trudna do uchwycenia zmiana. W powszechnej świadomości istnieje przekonanie, że nic nowego się nie wydarzyło. Przecież pornografia zawsze była obecna i nic się nie działo. Ludzie nadal kochają się, piszą wiersze, zakładają związki małżeńskie. Jednak nie jest to prawdą. O tym, co się wydarzyło, dowiadujemy się dopiero teraz. To, że dystrybucja pornografii przez Internet ma na człowieka toksyczny wpływ, nie jest łatwo zaakceptować. Aby to zrozumieć, potrzeba minimum wiedzy o neurofizjologii mózgu. Ta wiedza powszechnie nie jest znana i tutaj koło się zamyka. Zgadzamy się na konsumpcję trucizny, a tym, którzy nas przed tym przestrzegają, po prostu nie wierzymy. Obecnie pornografia dystrybuowana przez Internet jest:

- dostępna w każdym momencie

- bardzo stymulująca

- hiperrealistyczna

- odległa od rzeczywistych doświadczeń seksualnych.

Nieograniczona dostępność to coś więcej. To także niskie koszty lub ich brak. Konsument może po nią sięgać, kiedy tylko zechce. Smartfony to także małe komputery z możliwością swobodnego oglądania filmów. Ponieważ pornografia stanowi źródło stymulacji seksualnej, jest więc czynnikiem zmieniającym nastrój konsumenta. Czynniki, takie jak alkohol, narkotyki, hazard, zajadanie i inne konsumowane dla poprawy nastroju, przegrywają z nią właśnie pod względem dostępności. Odrębnym zagadnieniem jest dostęp dzieci do pornografii. Jest nieograniczony. To swoista tragedia, ale też dowód na utratę instynktu samozachowawczego całych społeczności. Jesteśmy na wojnie ideologicznej, o której trwaniu nie wiedzieliśmy zbyt długo. Dzisiaj całe rzesze ludzi zostały zrekrutowane, aby walczyć o jakże słuszną tolerancję, współczucie wobec mniejszości. Ludzie ci popierają zmiany społeczne i nie zdają sobie sprawy 
$\mathrm{z}$ tego, w czym naprawdę uczestniczą. Powiedzenie im, że partycypują w budowie nowego człowieka, nowego społeczeństwa, wywołuje agresję. Na tej wojnie mamy powszechny dostęp do pornografii zmieniającej neurofizjologiczne stosunki w mózgu człowieka (Zatorre, Fields, Johansen-Berg 2012, s. 528-536). Ten dostęp trwale modyfikuje sposób myślenia konsumenta oraz jego reakcje emocjonalne wobec tak ważnych elementów człowieczeństwa, jak relacja z drugim człowiekiem. Stanowi to ważny element, może nawet kluczowy.

Pornografia jest bardzo stymulująca. Tutaj właśnie tkwi istota sprawy. Dotychczasowa pornografia rozpowszechniana na nośnikach VHS, DVD, pendrive nie była w stanie dostarczyć do zmysłów człowieka takiej ilości bodźców $\mathrm{w}$ jednostce czasu jak ta internetowa, gdzie natychmiastowa zmiana planu (inny film) dostarcza bodźców w ilości ponadstandardowej. Człowiek od tysięcy lat nie miał z tym do czynienia. Stąd nie powinno dziwić, że mózg człowieka ulega przebudowie w czasie konsumpcji pornografii w ilościach toksycznych. Zakłada się, że jest to dwa razy w tygodniu i częściej ${ }^{1}$. Mózg uczy się funkcjonowania w nowej rzeczywistości. Jest to problem, ponieważ, aby to zrozumieć, trzeba minimum wiedzy o neurofizjologii mózgu, a wiedza ta wypełniona została odkryciami lat 1990-2019. Nie ma więc jej w świadomości powszechnej. Hiperstymulacja, czego dowiedziono nowoczesnymi metodami obrazowania mózgu człowieka, prowadzi do zwiększenia podaży dopaminy w układzie nagrody w mózgu ludzkim, a to początek zmian. Jeżeli doprowadzą one do uzależnienia, to mamy zespół kompulsywny (czynności przymusowych), zespół zniewalający człowieka. Jednakże umyka nam to, że bez uzależnienia nasz system wartościujący, który rozróżnia, co jest dobre, a co złe, czyni to zupełnie inaczej niż pod wpływem pornografii. W przypadku uzależnienia od niej inaczej zaczynamy oceniać, co jest dopuszczalne, a co nie jest, czym jest relacja z kobietą czy z mężczyzną. Wszystko się zmienia wewnątrz człowieka. Tak zwane parady równości mogą złościć, budzić nawet obrzydzenie. Jednak doceńmy ich obecność w przestrzeni publicznej, bo to one właśnie pokazują sformatowanego człowieka przyszłości. Możemy przyjrzeć się i odnieść do tego kierunku zmian. Wydaje się, że ludzie ci, pokazując światu swoją pokiereszowaną seksualność, informują nas o tej swoistej formacji nowego człowieka. Do zrozumienia tego zjawiska niezbędne staje się zrozumienie zmian w kulturze w obszarze komunikacji, gdzie zamiast komunikatów werbalnych obecnie kultura komunikuje się obrazem. W tym właśnie ujęciu obrazy z ulicy $\mathrm{w}$ trakcie parad równości są zbieżne $\mathrm{z}$ obrazami pornograficznymi w aspekcie likwidacji intymności jako wartości kulturowo pożądanej.

\footnotetext{
${ }^{1}$ Powszechnie uważa się, że częsta konsumpcja pornografii to jej codzienne, nawet kilka razy dzienne użycie dla celów stymulacji seksualnej. Tak częsta ekspozycja stanowi o wyjątkowo toksycznym wpływie na mózg.
} 
Nierealność treści to ważny element pornografii. W zakładkach dla przykładu „mother fuck”, „mom and son” i innych tego typu w treści przekazu zawarta jest sugestia, że matki marzą o współżyciu seksualnym ze swoimi synami. Czy tak jest w realnym świecie? To pytanie retoryczne. Należy więc zadać pytanie, jakie ma znaczenie utrwalenie takich potrzeb $\mathrm{z}$ obsesyjnym ich pojawianiem się $\mathrm{w}$ kontekście podniecenia seksualnego. Praktyka kliniczna pokazuje, że przy nieskutecznych próbach realizacji w realnym świecie pozostaje tylko przestrzeń wirtualna. Tak właśnie wytwarza się zjawisko ekskluzywności bodźca (Gola i in. 2016, s. 402). Tylko pornografia jest w stanie gratyfikować człowieka. Każdy inny bodziec seksualny staje się martwy. Brak gratyfikacji w realnym świecie poparty jest zmianami morfologicznymi w układzie motywacyjnym w korze przedczołowej mózgu człowieka - konsumenta pornografii (Kowalewska i in., s. 255-264). W kolejnej fazie konsument traci kontakt z rzeczywistością i zaczyna prezentować zachowania dewiacyjne w realnym świecie. Wydaje się, że to właśnie uczestnicy parad równości pokazują, jakie zachowania nieuchronnie mogą się pojawić u konsumenta pornografii. Grozy dodaje fakt, że to jest właśnie portret człowieka przyszłości, człowieka w ateistycznym raju, jaki jest budowany.

Pornografia w świadomości powszechnej postrzegana jest jako coś niewinnego. Przywołane poniżej wypowiedzi pacjentów nie pozostawiają miejsca na złudzenia: „wszechobecne i wszyscy oglądają”, ,jest dobre dla zdrowia”, „pozwala rozładować napięcie seksualne”, ,przez to jest mniej dewiantów”, „pozwala wzbogacić seks małżeński”, ,jest bezpieczną formą rozładowania”, ,jest alternatywną drogą rozładowania napięcia”2.

Gdy to analizujemy, pojawia się nieuchronnie problem skrzywień poznawczych (Brand i in. 2018, s. 104), którym ulega określony odsetek społeczeństwa. Termin skrzywienie poznawcze pochodzi z psychologii, z jej działu zajmującego się funkcjami poznawczymi mózgu człowieka. Najprościej skrzywienie lub - bardziej ogólnie - błąd poznawczy to nieracjonalne postrzeganie rzeczywistości. Wyniki badań populacji mężczyzn w Polsce mówią, że $96 \%$ z nich w roku 2018 miało kontakt z pornografią. To pokazuje prawdę o tym, gdzie się znajdujemy jako społeczność. Walka ideologiczna na tym etapie jest przegrana. Pornografia, a właściwie powszechne korzystanie z niej, jest znaczącą składową tej przegranej walki. W 2002 roku kontakt z pornografią w ciągu całego życia deklarowało $87,9 \%$ mężczyzn, a z pornografią w Internecie 36,6\%. W roku 2016 było to już 97,4\% mężczyzn, z czego 97,1\% korzystało z pornografii internetowej (Sun i in. 2016, s. 983-994).

${ }^{2} \mathrm{~W}$ trakcie pracy terapeutycznej autora tego typu treści pojawiają się w wypowiedziach osób uzależnionych. 
Jaki więc ten człowiek przyszłości ma być? Posłużmy się cytatami opisującymi, kim jest kobieta, wziętymi wprost z filmów pornograficznych. Kobiety to: worki na spermę, rury do dymania, kanapki, milfetki (mamuśki), mokre cipki, świeże dupencje, napalone stare pizdy, gorące szpary, skośnookie ździry, niegrzeczne uczennice i wiele innych podobnych. Można też wysłuchać opinii, np. „dobrze wiemy, czego chcesz i dokładnie to ci dajemy. Laseczki posuwane" ". Taki właśnie obraz kobiet zachowuje się w świadomości konsumenta pornografii. Przemoc wobec nich zawarta jest w $80 \%$ obrazów pornograficznych (Bridges 2010).

Nie dziwi chyba fakt, że to powoduje liczne problemy relacyjne. Kobiety oczekują, że ich partnerzy będą dostrzegali ich podmiotowość charakterystyczną dla człowieka. Nie chcą być „rurami do dymania”, a mimo to uczestniczą w paradach równości. Jak wytłumaczyć tym kobietom, że aby zobaczyć, co się dzieje, powinny przestać współczuć innym, bo na współczuciu właśnie opiera się strategia animatorów zmian społecznych, w jakich uczestniczymy? Jak przestać współczuć tym, którzy z wykluczenia stworzyli sobie źródło dochodu? To wydaje się awykonalne. Właśnie tu tkwi problem, bo chociaż kobieta nie chce stać się „workiem na spermę”, zapewne nieświadomie popiera zmiany prowadzące do uprzedmiotowienia przedstawicielek swojej płci. W nowym świecie już nie będzie budzącą szacunek matką, a „gorącą szparą". Jak bardzo problem ten jest widoczny, pokazał ostracyzm medialny, jaki spotkał arcybiskupa Jędraszewskiego po jego wypowiedzi o „tęczowej zarazie”. Słowa te dotyczyły zapewne antywartości, jakie promują tak zwane parady równości. Jednak, jeżeli zauważymy, że parady te ukazują człowieka przyszłości, to w tym miejscu pornografia oraz ruch umownie nazwany LGBT schodzą się w jednym miejscu.

Pornografia to zjawisko o zasięgu światowym.

- Tylko z jednego, najpopularniejszego serwisu dystrybuującego pornografię internetową w 2017 roku korzystało dzi ennie około $81 \mathrm{mi-}$ lionów osób.

- Roczna liczba odwiedzin to 28,5 miliarda.

- Suma czasu wszystkich dostępnych filmów pornograficznych to łącznie 68 lat.

- Ilość przesłanych danych podczas ich oglądania to 3732 petabajty (Gola 2018).

Możemy to nazwać doświadczeniem na współczesnym człowieku. Światowy zasięg zjawiska nie pozostawia złudzeń co do konsekwencji społecznych

\footnotetext{
${ }^{3}$ Treści ogólnie dostępne na stronach publikujących obrazy pornograficzne.
} 
konsumpcji pornografii. Poprzez zmiany w mózgu człowieka ma silnie uzależniający wpływ. Skok dopaminy w układzie nagrody jest ponadstandardowy. Badania jednoznacznie pokazują zjawisko tak zwanej neuroplastyczności mózgu, czyli zdolności do zmiany swojej morfologii (budowy) poprzez stymulację silnymi bodźcami zmieniającymi emocje, a wpływającymi na układ nagrody (Voon i in. 2016).

Przy dzisiejszych możliwościach technicznych jesteśmy w stanie ustalić poziom dopaminy - neuroprzekaźnika w układzie nagrody w mózgu ludzkim (grzbietowo-boczna kora przedczołowa, brzuszne prążkowie i kora przedczołowa) - w stanie pobudzenia określonymi bodźcami chemicznymi czy też wzrokowymi.

\section{Im większy i częstszy skok dopaminy w mózgu, tym większe ryzyko uzależnienia.}

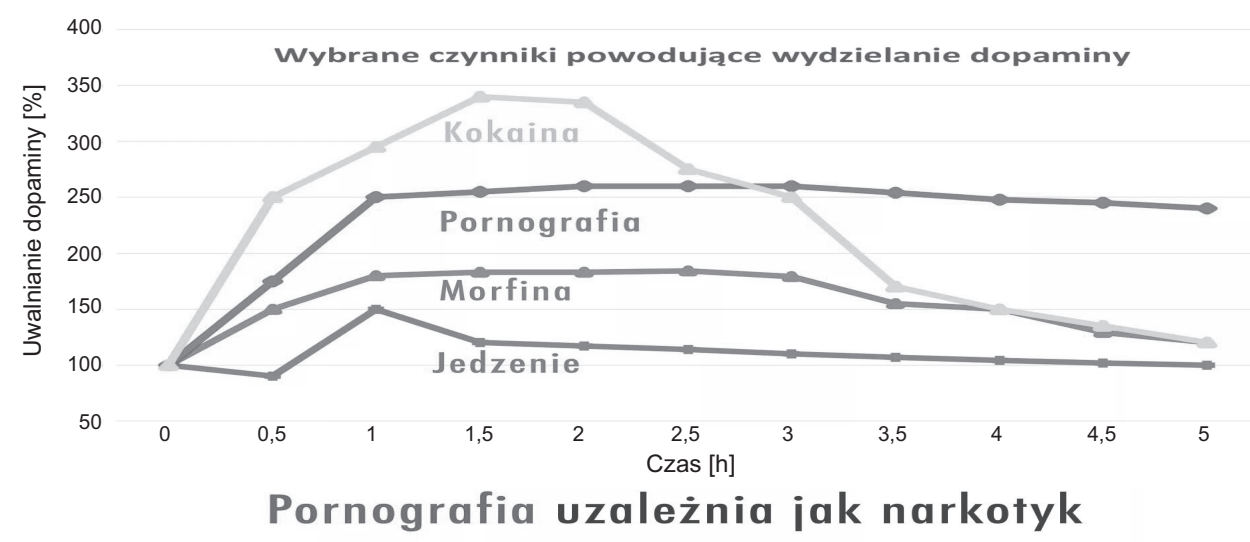

I W O J A S P R A W A

Okazuje się, że pornografia w swojej współczesnej formie prowadzi do uzależnienia od tego rodzaju bodźców u przynajmniej 11\% konsumentów (Gola $\mathrm{i}$ in. 2017). Nie oznacza to zarazem braku zmian w sposobie myślenia, odniesienia wewnętrznego do własnego podniecenia, wyboru obiektu seksualnego czy w aparacie definiującym dobro i zło i w innych obszarach człowieczeństwa. Zmiany te są obecne, natomiast różnica wynikająca ze stanu uzależnienia konsumenta polega na utracie kontroli nad własnym zachowaniem. Zespół obsesyjno-kompulsywny, jaki towarzyszy uzależnieniu się od pornografii, nie różni się od zmian, jakie towarzyszą innym uzależnieniom, zwłaszcza jeżeli chodzi o układ nagrody oraz system motywacji w mózgu. Oczywisty 
jest w tej sytuacji deficyt empatii i współczucia, co zawsze ma miejsce u osób uzależnionych, przeorientowanie motywacji do działania oraz inna formuła funkcjonowania pamięci operacyjnej w mózgu. To w następstwie stanowi źródło spadku produktywności osób uzależnionych, ich niewielką kreatywność, trudności w koncentracji, zaburzenia pamięci (Valkenburg, Peter 2008), które są obecne w zespole uzależnienia od pornografii. Prowadzi to do zjawiska pojawienia się cyklu uzależnieniowego, który charakteryzuje się okresami pobudzenia, tak zwanego acting-out, z okresami ciszy i spokoju. Cykl ten ma podstępną wartość. W okresie ciszy i spokoju osoba uzależniona utwierdza się w przekonaniu, że wszystko jest w porządku. „Poradziłem sobie z nałogiem, skoro mogłem przestać". Nic bardziej mylnego, choroba toczy się dalej (materiał własny autora). W kalendarzu zapisuje kolejny dzień pobudzenia poprzedzonego charakterystycznym dla osoby wyzwalaczem.

\section{Etapy cyklu nałogowego}

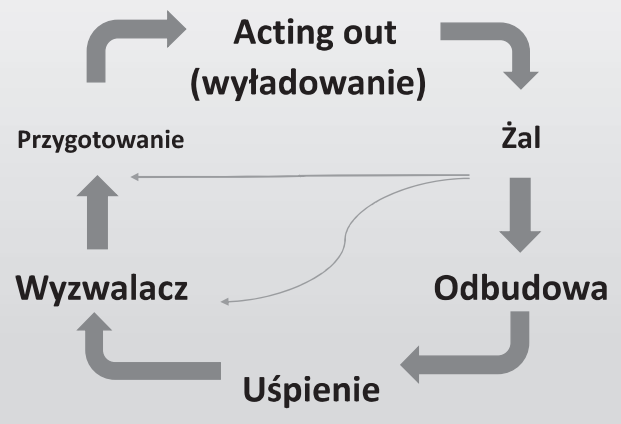

Niezmiernie interesującym faktem jest brak obecności choroby w Międzynarodowym Spisie Chorób (ICD-10), która przedstawiona by była zgodnie z zespołem opisanym jako uzależnienie od pornografii. Ponieważ klasyfikacja ta stanowi źródło prawa medycznego, to oznacza, że chociaż choroba istnieje, powoduje cierpienie, leczenie jej odbywa się w kwalifikowanych ośrodkach, to jednak „szanowne” grono ustalające treść tej klasyfikacji nie było skłonne uznać dotychczas tego zjawiska za chorobę i długie lata nie chciało jej dostrzec. Dopiero wobec masowości uzależnień w skali światowej w nowej klasyfikacji, która wejdzie w życie, zespół kompulsywnych zachowań seksualnych został dookreślony. Nieuchronnie przypomina to komisję senacką pod 
przewodnictwem Henry'ego Waxmana, senatora z Kalifornii, przed którą producenci tytoniu pod przysięgą kłamali, że nikotyna nie uzależnia palaczy. Podobnie było także w przypadku tabletek na kaszel z heroiną, które produkował Bayer, tabletek na odchudzanie $\mathrm{z}$ amfetaminą i innych wyjątkowo szkodliwych produktów aplikowanych ludziom z chęci zysku przez ubiegłe lata.

Klasyfikacja ICD-11 będzie dopiero wprowadzona od stycznia 2022 roku. Do tego czasu w świetle prawa medycznego uzależnienia od pornografii leczone są w zasadzie nielegalnie, natomiast jej propagatorzy mają alibi - przecież uzależnienia od niej nie ma. Ze smutkiem należy tutaj przywołać - „łatwiej wielbłądowi przejść przez ucho igły niż bogatemu wejść do Królestwa Bożego" (Mt 19,4). Prawdziwość tych słów jest w tej sytuacji szczególnie widoczna. W danych zaprezentowanych w roku 2015 na konferencji w Sejmie RP amerykańscy badacze pornografii mówili o miliardowym interesie, w którym w każdej minucie producenci pornografii zarabiają kilkadziesiąt tysięcy dolarów (Sejm RP 2015). To może tłumaczyć wybiórczą ślepotę „szanownych” gremiów z WHO, które nie były dotąd w stanie dostrzec problemu z uzależnieniem. Szczęśliwie nauka jeszcze się nie poddała w tym sporze pomiędzy interesem bogatego a szkodą jednostki. Badania nad uzależnieniem od pornografii, szczególnie prowadzone po roku 2000, jednoznacznie pokazały bezmiar patologii mózgu u osób uzależnionych. Badania obecnie prowadzone są na poziomie molekularnym, a ich wyniki pozwalają już mówić o przewlekłej chorobie mózgu u osoby uzależnionej. Pojawiają się też coraz bardziej wstrząsające informacje na ten temat. Choćby ta o stwierdzanej mniejszej ilościowo warstwie istoty szarej w mózgu osób z uzależnieniem od pornografii (Gola 2018). Nauka nie odpowiedziała jeszcze na pytanie, czy stan ten poprzedza uzależnienie i sprzyja mu, czy jest to konsekwencja, czy też oba zjawiska mają miejsce. Jednak wymowa stwierdzanego faktu jest wstrząsająca. Nauka ma wiele jeszcze do odkrycia w ramach badania istoty przewlekłej choroby mózgu, jaką konsumpcja pornografii powoduje u niektórych osób. Trudno jednak nie wspomnieć, że nadchodzi epoka relatywizowania wszystkiego, nauki też. Szaleństwo, jakie pojawiło się w związku z określaniem płci człowieka, które wbrew nauce w dowolny sposób buduje w ludziach przekonanie o istnieniu kilkudziesięciu płci, nie wróży niczego dobrego. Może tak być, że badacze dowiedzą się, co zachodzi w mózgu osoby uzależnionej, lecz nikt już nie będzie chciał o tym słuchać. Już teraz na wykładach o szkodliwości pornografii pojawiają się osoby propagujące neomarksistowskie wybryki umysłu, jak chociażby mnożenie nieistniejących w świetle nauki niezliczonych płci człowieka, a osoby skażone myśleniem zgodnym z promującymi obecnie permisywne wychowanie seksualne, tak zwanymi, środowiskami LGBT kompletnie nie są zainteresowane szkodliwością pornografii. Logiczną konsekwencją skażenia nią w okresie adolescencji jest to, że większość jej konsumentów, których 
pierwszy kontakt z nią przypada pomiędzy 12-14 rokiem życia, w dorosłym życiu będzie wyznawać liberalne poglądy. Pornografia formatuje człowieka w taki sposób, że już jako dorosła osoba odrzuci posiadaną wiedzę na rzecz napędzanych emocjonalnym podglebiem poglądów, zgodnych z wcześniej utrwalonymi potrzebami.

Konsekwencje konsumpcji pornografii bywają rozmaite w różnych płaszczyznach ludzkiej aktywności. Dotyczą zdrowia seksualnego i przejawiają się w postaci: dysfunkcji seksualnych (dla przykładu mogą to być zaburzenia wzwodu, wytrysku), problemów relacyjnych, rozpadu związków, trudności osobistych (deficytu produktywności zauważanego w pracy), zaburzeń nastroju (depresji) i wielu innych ${ }^{4}$.

- Pornografia redukuje zdolność do miłości.

- Pornografia redukuje potrzebę budowania więzi, zastępując je potrzebami promiskuityzmu, czyli wyłącznie redukcji napięcia poprzez seks.

- Pornografia powoduje narastanie potrzeb seksualnych z użyciem przemocy seksualnej.

- Pornografia czyni uzależnionego człowiekiem samotnym pośród tłumu.

- Pornografia redukuje potrzebę zakładania rodziny.

- Pornografia sprzyja postawom z presją na zmiany norm kultury na pasujące do uzależnienia (prawo, obyczajność, moralność, religia).

- Zwielokrotnia liczbę osób dotkniętych dewiacjami seksualnymi.

Wszystkie te konsekwencje narastają powoli, niemalże niezauważalnie. Jeżeli na początku drogi konsumenta informuje się, że jest narażony w przyszłości na pożądanie seksualne dziecka, to z pewnością odpowie, że nie jest to możliwe. Jednak w praktyce opiniowania sądowego pornografia ma coraz bardziej stwierdzaną przyczynowość w czynach pedofilnych, dokonanych przez sprawców sądzonych w związku z czynem zabronionym. Pojawianie się coraz częściej w środowiskach tak zwanych LGBT osób jawnie zabiegających o zniesienie penalizacji pedofilii nie powinno nikogo w tym kontekście dziwić. Podstępność wpływu pornografii polega na nieuchronności zmian w mózgu konsumenta przy równoczesnym powolnym, wieloletnim przebiegu procesu, gdzie zmiany narastają niezauważalnie. Ów zapytany nie zauważy nawet momentu, kiedy zacznie poszukiwać filmów do stymulacji seksualnej z coraz młodszymi aktorami i wejdzie w obszar pornografii dziecięcej, będzie to dla

\footnotetext{
${ }^{4} \mathrm{~W}$ trakcie pracy terapeutycznej autor zaobserwował, że zaburzenia erekcji oraz wytrysku, problemy relacyjne, a także zaburzenia depresyjne z dużą częstotliwością występują u osób uzależnionych od pornografii.
} 
niego niedostrzegalne. Pojawianie się coraz większej odporności na bodźce uruchomi zjawisko eskalacji bodźca poszukiwanego, kiedy te dotychczasowe nie są już gratyfikujące. Nauka nie zna jeszcze odpowiedzi na pytania, co różnicuje ludzi pod kątem podatności na te procesy, bo szybkość ich przebiegu u poszczególnych osób jest różna. Natomiast samo zjawisko jest obecne zawsze.

Społeczne konsekwencje pornografii obok już nadmienionych w postaci zmiany preferencji do oczekiwanych stosunków społecznych są badane szczegółowo. Można już bez wątpienia wymienić następujące skutki pornografii:

- Konsekwentnie narasta grupa młodych mężczyzn wchodzących w życie z uszkodzoną sferą seksualną.

- Odnotowuje się wzrost zachowań agresywnych w sferze seksualnej młodzieży.

- Zachodzą gwałtowne zmiany kodeksu obyczajowego.

- Dochodzi do rewizji zakresu czynów penalizowanych (zmiany prawa).

- Narastająca liczba osób uzależnionych od pornografii skutkuje reorientacją we wzorcach rodziny.

- Następuje przeobrażenie postrzegania roli i pozycji społecznej kobiet.

- Dokonuje się metamorfoza w świadomości zbiorowej, czym jest bliskość seksualna.

- Konsekwentnie stępia się wrażliwość na seksualizację oraz pornografię.

Swoistym memento dla zmian społecznych pod wpływem pornografii powinny być konsekwencje, które dotknęły Japonię (Mc Neill 2009). Należy jednak powiedzieć, że przemiany te ułatwiła wstępna słabość rodziny japońskiej. Jednak ich wymowa jest tragiczna. Około 70\% kawalerów japońskich w wieku pomiędzy 24-35 lat nie jest zainteresowanych jakimkolwiek kontaktem fizycznym z kobietą. To zapewne stanowi główną przyczynę postępującego spadku dzietności Japończyków. To społeczeństwo gwałtownie się starzeje, a niski przyrost naturalny nie kompensuje umieralności. Na uzasadnienie związku konsumpcji pornografii z uzyskanymi danymi z Japonii można chociażby uwzględnić porównanie przychodu z pornografii internetowej w Japonii i Niemczech w roku 2006 - 19,98 miliardów USD v. 0,64 miliarda USD w Niemczech (Ropelato 2014).

Powstaje pytanie: Czy może to jakaś moda, która jak wiele innych przeminie? Oby tak było. Jednak logiczne argumenty przeczą temu. Najlepiej obrazuje problem cytowana poniżej wypowiedź jednego z twórców pornografii: „Jeżeli chodzi o porno i rynek ekscentrycznych doznań, w tym gonzo, wielu ludzi chce dziś oglądać coraz bardziej ekstremalne wyczyny, więc nieustan- 
nie staram się wymyślać coś nowego" (Jordan 2003). Wypowiedź ta pokazuje dryfowanie pornografii w kierunkach bardziej drastycznych obrazów, co bacznie jest obserwowane. Nie można powiedzieć, że osiągnęliśmy dno upadku. Będzie tylko gorzej. Należy raczej wątpić, aby ktokolwiek zrobił coś radykalnego, dopóki nie znajdziemy się w takiej sytuacji, jak Japonia, i nie okaże się, że na nasze emerytury nie ma już kto pracować. Dopóki nie pojawi się powód ekonomiczny, pozostaje apelowanie do wyobraźni. Jednak w świecie, w którym obraz zastąpił słowo, a czytanie i myślenie przestaje być tren$d y$, „światełko w tunelu” przestaje być widoczne. Wahadło dziejowe przeszło w budzący niepokój stan wychylenia. Widać, jak skrajny feminizm pomagał w zaimportowaniu (i dalej zresztą pomaga) koszmarnych obyczajów z „trzeciego" świata, obyczajów, zgodnie z którymi kobietę traktuje się w sposób pozbawiony elementarnego szacunku należnego człowiekowi. Pornografia, jej niekiedy codzienna konsumpcja, ma przygotować współczesnego człowieka krajów wyrosłych na zrębach kultury chrześcijańskiej do braku szacunku. W Szwecji, kraju dotychczas tak spokojnym, że aż nudnym, gwałt na kobiecie jest jednym z najczęściej statystycznie popełnianych czynów, w dodatku kary za te przestępstwa są niezwykle niskie, spowodowane jest to tak zwanym „,nowym myśleniem" w tamtejszym wymiarze sprawiedliwości. Połączenie akceptacji przez feministki dla gwałcenia kobiet, bo jak inaczej można nazwać ich zachwyt wobec importu islamu do Europy, z uwalnianiem kobiet z ucisku, jakiego podobnież doznają w społeczeństwie opartym na wartościach chrześcijańskich, jest dla człowieka myślącego (homo sapiens) niemożliwe do zaakceptowania. Bezrefleksyjna akceptacja skonfliktowanych wartości dokonująca się w narracji lewicowej prowadzić musi do konfliktów społecznych o skali niedającej się przewidzieć. Ten proces będzie dewaluował zapewne neomarksizm, czy też postmodernizm, ich atrakcyjność musi w takim procesie jednak maleć. Na razie jest tak, że zgwałcony homoseksualnie dziennikarz niemiecki przez imigranta z północy Afryki nadal po długim leczeniu wyznaje ideologię multikulturalizmu. To jeszcze nie ten poziom cierpienia, aby zmusić tego pana do myślenia. Na dzień dzisiejszy procesy logiczne Europejczyków nie pozwalają na skojarzenie importu trzeciego świata do Europy z konsekwencjami, zamiast eksportu naszych zasad na tereny trzeciego świata, oraz z narastaniem patologii społecznej, o której dotychczas słyszeli wyłącznie z mediów. Profesor Mateusz Gola w swoich badaniach ujawnia, że zmniejsza się warstwa kory mózgowej u osób uzależnionych od pornografii, lecz nie odpowiada na pytanie, czy chodzi o pierwotnie uboższą korę mózgową i stąd podatność na uzależnienie, czy jest to skutek konsumpcji pornografii w postaci przebudowy mózgu, czy też jedno i drugie. Nie zajmując stanowiska w obszarze jeszcze nieodkrytym w nauce, można $\mathrm{z}$ całą pewnością połączyć w jakiejś mierze tę bezrefleksyjną i emocjonalnie napędzaną u jednostek 
zakażonych pornografią podatność na indoktrynację $\mathrm{z}$ akceptacją skonfliktowanych wartości, które logicznie się zarazem wykluczają. Tak jak to się dzieje, gdy importujemy islam do Europy, będącej zarazem obszarem, gdzie tak mocno walczymy z uciskiem kobiety przez dotychczasowe stosunki społeczne. Homo, aut quo vadis, ku światłu, czy w mrok. Na razie chyba nie sposób tego ocenić. To wiara miała przeszkadzać nauce. Proces Galilleusza, choć to jedyny przypadek, gdzie Kościół zajął oficjalne stanowisko na gruncie nauki, zresztą całkowicie błędne, ma być tego dowodem. Pojawienie się rewolucji seksualnej, wspartej przez filozofię podważającą racjonalne myślenie, niszczy naukę u podstaw. Dlatego właśnie mamy obowiązek wypowiadania się na temat zjawiska, jakim jest pornografia. Musi być ona widziana, bo tym właśnie jest jako element rewolucji seksualnej w kolejnym jej wydaniu po klęsce tej pierwszej zapoczątkowanej przez Wilhelma Reicha. To on właśnie po napisaniu w roku 1929 pracy Materializm dialektyczny a psychoanaliza rozpoczął tworzenie sieci poradni seksuologicznych w robotniczych dzielnicach Wiednia, a potem Berlina. Warto przypomnieć tezy Reicha: „system społeczny, tworzy etos pracy, tłumi popęd seksualny i dla jego wyzwolenia konieczna jest rewolucja społeczna, to wyzwolenie popędu seksualnego powinno zniszczyć etos pracy, czyli podstawę tego systemu, a zatem doprowadzić do jego upadku, a władzę nad społeczeństwem obejmą ci, którzy przeprowadzą rewolucję seksualną" (Karoń 2019).

Skoro jeszcze myślimy, mimo dużej liczby ludzi używających wyłącznie emocji do opisu świata, to mamy obowiązek dzielenia się z innymi efektami naszych logicznych analiz na temat tego, z czym mamy do czynienia w szybko zmieniającym się świecie. Kilka przemyśleń na temat pornografii zawartych w tej pracy stanowi właśnie taką próbę.

\author{
PORNOGRAPHY AND ITS IMPLICATIONS \\ FOR THE MENTAL, MORAL AND SOCIAL LIFE
}

\title{
Summary
}

There are not many studies concerning the social implications of pornography. This paper shows how variuos implications of pronography are linked to each other; how its emotional consequences contribute to its social consequences. This aspect of pornography is commonly ingnored which makes it particularly dangerous. The paper also reviews what was recently written about pronography from this point of view. Thus it may be a form of an alert for the man who lives in the present western society. 
Key words: pornography, brain disease, chemical changes in the brain, social implications of pornography, the cultural changes, the society of the future.

Słowa kluczowe: pornografia; choroba mózgu; chemiczne zmiany w mózgu; społeczne skutki pornografii; zmiany w kulturze; społeczeństwo przyszłości

\section{BIBLIOGRAFIA}

Brant M., Wegmann E., Muller A., Stark R. (2019), The Interaction of Person Affect - Cognition-Execution (I-PACE) Model for addictive Behaviors: Update, generalization to addictive behaviors beyond Internet - use disorders and specification of the process character of addictive behaviors, „Neuroscience \& Biobehavioral Reviews” (06), s. 104.

Bridges A., Wosnitzer R., Scharrer E., Sun Ch., Liberman R. (2010), Aggression and Sexual Behavior in Best Selling Pornography Videos: A Content Analisys Update, „Violence Against Women”, https://journals.sagepub.com/doi/abs/10.1177/1077801210382866 [dostęp: 26.10.2010].

Davis A., Carrotte E., Hellard M., Temple-Smith M., Lim M. (2017), P4.11 "I think it has been a negative influence in many ways but at the same time I can't stop using it": self-identified problematic pornography use among a sample of young australians, „Behavioural and Social Science Research"2(93), https://sti.bmj.com/content/93/Suppl_2/A195.3 [dostęp: 01.07.2017].

Gola $\mathrm{i}$ in. (2017), Can Pornography be Addictive? An fMRI Study of Men Seeking Treatment for Problematic Pornography Use, ,Neuropsychopharmacology”, 42, s. 2021-2031. DOI:10.1038/ npp.2017.78.

Gola i in. (2016), Visual Sexual Stimuli - Cue or Reward? A Perspective for Interpreting Brain Imagin. Finding on Human Sexual Behaviors, ,Frontiers in Human Neuroscience” 10(402), https:// www.ncbi.nlm.nih.gov/pmc/articles/PMC4983547/, [dostęp: 15.08.2016].

Gola M. (2018), Co wiemy o uzależnieniu od pornografii oraz o tym, w jaki sposób korzystaja z niej dzieci i młodzież, Konferencja - Masowa konsumpcja pornografii przez dzieci jako istotny problem społeczny, Warszawa, 21.11.2018.

Jules Jordan Reżyser filmów porno (2003). Adult Video News, styczeń 2003 r., s. 60

Karoń K. (2019), Historia antykultury 1.0, Warszawa.

Kowalewska, E., Grubbs, J.B., Potenza, M.N. i in. (2018), Neurocognitive Mechanisms in Compulsive Sexual Behavior Disorder, „Current Sexual Health Reports” (10), s. 255-264, https://doi. org/10.1007/s11930-018-0176-z [dostęp: 12.11.2018].

Materiały z konferencji (2015), „Spoleczne i rozwojowe konsekwencje pornografii”, Warszawa, Sejm RP, 22.06.2015.

Mc Neill D. (2009), Japan's generation-xx, https://www.independent.co.uk/news/world/asia/japans-generation-xx-1704155.html [dostęp: 13.06.2009].

Mialon A., Berchtold A., Michaud P.A., Gmel G., Suris J.C. (2012), Sexual Dysfunctions Among Young Men: Prevelence and Associated Factors, „Journal of Adolescent Health”, https://doi. org/10.1016/j.jadohealth.2012.01.008 [dostęp: 16.03.2012].

Ropelato J. (2014), Internet PornographyStatistics, „TopTenReviews”, 28.03.2014.

Sun Ch., Bridges A., Johnson A.J., Ezzel B.M. (2016), Pornography and the Male Sexual Script; An Analyssis of Consumption and Sexual Realations, „Archive of Sexual Behavior” (45), s. 983$-994$.

Szczypiński J.J., Gola M. (2018), Dopamine Dysregulation Hypothesis The Common Basis For Motivational Anhedonnia in Major Depressive Disorder and Schizophrenia?, https://doi.org/ 10.1515/reneur-2017-0091 [dostęp: 24.03.2018].

Środa M. (2009), Kobiety $i$ władza, Warszawa. 
Valkenburg M.P., Peter J. (2008), Adolescents Identity Experiments on the Internet: Cosequences for Social Competence and Self-Concept Unity, https://journals.sagepub.com/doi/10.1177/ 0093650207313164_[dostęp: 1.04.2008].

Voon V., Schmidt C., Morris S.L., Kvamme L.T., Hail P., Birchard Th. (2016), Compulsive sexual behavior: Prefrontal and limbic volume and interactions, https://doi.org/10.1002/hbm.23447 [dostęp: 27.10.2016].

Zatorre R., Fields R., Johanse-Berg H. (2012), Plasticy In Gray And White: Neuroimagin Chages In Brain Structure During Learnig, „Nature Neuroscience” 15 (4), s. 528-536.

Bogdan Stelmach - lekarz specjalista seksuolog, terapeuta seksualny, badacz współczesnej kultury szczególnie w aspekcie zmian w obszarze seksualności człowieka. 